\title{
Splanchnic energy expenditure and net nutrient flux in sheep fed diets with varying concentrate:forage ratios*
}

\author{
M.J. Del Sole, M.I. Recavarren and G.D. Milano ${ }^{1}$ \\ Departamento de Fisiopatología, Facultad de Ciencias Veterinarias, \\ Universidad Nacional del Centro, Campus Universitario \\ 7000, Tandil, Buenos Aires, Argentina
}

\begin{abstract}
Six wethers, fitted with permanent catheters in the femoral artery and splanchnic blood vessels, were used in a balanced, incomplete block design to evaluate the effect of increasing the proportion of concentrate (cracked maize:soyabean meal, 90:10; T0, 0 g/kg DM; T30, 300 g/kg DM; T60, 600 g/kg $\mathrm{DM})$ in the diet, at near maintenance energy intake $\left(385 \pm 5.0 \mathrm{~kJ} \mathrm{EM} / \mathrm{kg}^{0.75}\right)$, on $\mathrm{O}_{2}$ consumption and net flux of energy metabolites and $\mathrm{NH}_{4}^{+}$across the portal-drained viscera (PDV) and liver. Increasing the proportion of concentrate in the diet altered $\mathrm{PDV} \mathrm{NH}_{4}^{+}$absorption $(\mathrm{P}<0.001$; quadratic effect, $\mathrm{P}=0.04)$, liver $\mathrm{NH}_{4}^{+}$removal (quadratic effect, $\mathrm{P}=0.08$ ) and $\beta-\mathrm{OH}$-butyrate production (quadratic effect, $\mathrm{P}=0.09$ ). However, the increased concentrate:forage ratio did not affect $\mathrm{O}_{2}$ consumption by the PDV, or the net flux of glucose and lactate across the PDV, liver or splanchnic tissues. $\mathrm{O}_{2}$ consumption by the liver tended to decrease (linear effect, $\mathrm{P}=0.06$ ) with increased concentrate:forage ratio in the diet. Increased concentrate:forage ratio might increase nutrient availability to peripheral tissues by reducing the energy expenditure of the liver.
\end{abstract}

KEY WORDS: sheep, concentrate, splanchnic tissues, energy expenditure, $\mathrm{O}_{2}$ consumption, ammonia

\section{INTRODUCTION}

In ruminants, the splanchnic tissues represent only 0.2 of total body mass, but their high metabolic rate can account for up to 0.5 of whole body energy and protein demands. Energy and protein metabolism of splanchnic tissues has been shown to vary with dry matter intake, energy intake and diet composition, and this can determine the quantity and pattern of energy and $\mathrm{N}$ substrates available for productive purposes (Huntington, 1989; Reynolds et al., 1991). The objective

\footnotetext{
* Supported by Research Project PICT08-03881, ANPCyT, Argentina

${ }^{1}$ Recipient of a Research Scholarship from ANPCyT and CICPBA, Argentina

${ }^{1}$ Corresponding author: e-mail: gmilano@vet.unicen.edu.ar
} 
of this study was to determine the effect of diets with varying concentrate:forage ratios, fed at equal DE intake, on splanchnic energy expenditure (EE) and net flux of energy metabolites and $\mathrm{NH}_{4}^{+}$in sheep.

\section{MATERIAL AND METHODS}

\section{Animals and design}

Six Corriedale wethers $(43 \pm 4.5 \mathrm{~kg} \mathrm{BW})$, maintained in individual pens (2.6 $\mathrm{m}^{2}$ ) under natural lighting, were surgically implanted with chronic indwelling catheters in the posterior aorta, and the mesenteric, the portal and the hepatic veins and allowed to recover from surgery for 3 weeks. In two consecutive experimental periods of 4 weeks, animals were fed, at near maintenance energy intake $(385 \pm 5$ $\mathrm{kJ} \mathrm{EM} / \mathrm{kg}^{0.75}$ ), 2 out of 3 experimental diets: $1000 \mathrm{~g}$ lucerne hay DM (chopped to average length of $4-5 \mathrm{~cm} ; 8.8 \mathrm{MJ} \mathrm{ME}$ and $25.0 \mathrm{~g} \mathrm{~N} / \mathrm{kg} \mathrm{DM}$; T0), $700 \mathrm{~g}$ lucerne hay and $300 \mathrm{~g}$ concentrate DM (cracked maize grain:soyabean meal, 90:10; 10.6 MJ $\mathrm{ME}$ and $23.1 \mathrm{~g} \mathrm{~N} / \mathrm{kg} \mathrm{DM}$; T30) or $300 \mathrm{~g}$ lucerne hay and $700 \mathrm{~g}$ concentrate DM (12.3 MJ ME and 20.6 g N/kg DM; T60), in a balanced incomplete block design. Diets were fed in 6 equal meals, delivered every $4 \mathrm{~h}$ by automatic feeders. Water was offered ad libitum. Amounts fed were adjusted for body weight changes every 4 weeks.

\section{Infusions, samples and analysis}

A 5-day faeces collection was performed at the end of each experimental period. Aliquots of feedstuffs and faeces were dried at $60^{\circ} \mathrm{C}$ to determine $\mathrm{DM}$ content. On the last day of the experimental period, a solution of $100 \mathrm{mM} p$ aminohippuric acid (pAH) and $500 \mathrm{IU}$ heparin $/ \mathrm{ml}$, was infused $(0.34 \mathrm{~g} / \mathrm{min})$ for 5 $\mathrm{h}$ into the mesenteric vein catheter. After $1 \mathrm{~h}, 3$ simultaneous and continuous $(0.1$ $\mathrm{ml} / \mathrm{min}$ ) blood samples were withdrawn from the artery and the portal and hepatic veins into plastic syringes maintained in ice-cold $\left(5^{\circ} \mathrm{C}\right)$ water, every $80 \mathrm{~min}$, using a peristaltic pump. Blood samples were thoroughly mixed and analysed for $\mathrm{pO}_{2}$, $\mathrm{pCO}_{2}$ and $\mathrm{pH}$ (Blood Gas Analyser), haemoglobin, packed cell volume and $\mathrm{pAH}$ concentration (Milano et al., 2000). Plasma, obtained by centrifugation of blood at $1000 \mathrm{~g}\left(4^{\circ} \mathrm{C}\right.$ ), was analysed for $\mathrm{NH}_{4}^{+}$, glucose (Milano et al., 2000), lactate (Lactate, Randox ${ }^{\circledR}$ ) and $\beta-\mathrm{OH}-$ butyrate $\left(\right.$ Ranbut, Randox $\left.{ }^{\circledR}\right)$.

\section{Calculations and statistical analysis}

Net fluxes of $\mathrm{O}_{2}$ and metabolites across the portal-drained viscera (PDV) and the liver were calculated as described by Milano et al. (2000).

Results were analysed by ANOVA. Orthogonal contrasts were used to examine linear and quadratic effects using the GLM procedure of SAS, V 8.2 (SAS, Institute Inc., Carry, NC, USA). 


\section{RESULTS AND DISCUSSION}

The hepatic catheter lost patency in two animals, so that only 8 data points were left for blood flow in the hepatic vein, net fluxes across liver, splanchnic tissues as well as liver and splanchnic EE. In order to account for the unbalanced data, least square means, rather than arithmetic means, were estimated for these variables (Table 1).

Table 1. Dry matter (g/d) and digestible energy (DE; $\mathrm{kJ} / \mathrm{d} / \mathrm{kg}{ }^{0.75}$ ) intake, splanchnic blood flow (ml/ $\mathrm{min}$ ), net mass transfers of oxygen and metabolites across portal drained viscera (PDV), liver and splanchnic tissues $(\mu \mathrm{mol} / \mathrm{min})$ and splanchnic energy expenditure $\left(\mathrm{EE} ; \mathrm{kJ} / \mathrm{d} / \mathrm{kg}{ }^{0.75}\right)$ in wethers

\begin{tabular}{|c|c|c|c|c|c|}
\hline & T0 & T30 & T60 & RSD & $\mathrm{P}$ \\
\hline DM intake & $726^{\mathrm{a}}$ & $649^{\mathrm{b}}$ & $549^{c}$ & 13.0 & 0.001 \\
\hline DE intake & 472 & 497 & 462 & 51.0 & 0.92 \\
\hline \multicolumn{6}{|l|}{ Blood flow } \\
\hline portal vein ${ }^{1}$ & 1614 & 1809 & 1434 & 279.8 & 0.43 \\
\hline hepatic vein & 1939 & 1786 & 1436 & 290.5 & 0.62 \\
\hline \multicolumn{6}{|l|}{ Net mass transfers } \\
\hline \multicolumn{6}{|l|}{$P D V$} \\
\hline $\mathrm{O}_{2}$ & -1596 & -1243 & -875 & 331.0 & 0.42 \\
\hline glucose & -45 & 136 & 162 & 198.5 & 0.47 \\
\hline lactate & -85 & 100 & 127 & 61.8 & 0.29 \\
\hline$\beta$-OH-butyrate & 60 & 59 & 117 & 62.9 & 0.28 \\
\hline $\mathrm{NH}_{3}$ & $532^{\mathrm{a}}$ & $614^{\mathrm{b}}$ & $284^{\mathrm{c}}$ & 34.8 & 0.001 \\
\hline \multicolumn{6}{|l|}{ Liver $^{2}$} \\
\hline $\mathrm{O}_{2}$ & -1721 & -1293 & -1068 & 150.2 & 0.11 \\
\hline glucose & 284 & 361 & 301 & 111.1 & 0.79 \\
\hline lactate & -33 & -147 & -65 & 115.5 & 0.66 \\
\hline$\beta$-OH-butyrate & 87 & 103 & 58 & 11.0 & 0.09 \\
\hline $\mathrm{NH}_{3}$ & -537 & -675 & -261 & 97.3 & 0.08 \\
\hline \multicolumn{6}{|l|}{ Splanchnic tissues ${ }^{l}$} \\
\hline $\mathrm{O}_{2}$ & -3458 & -2446 & -2223 & 472.1 & 0.25 \\
\hline glucose & 427 & 332 & 471 & 324.0 & 0.89 \\
\hline lactate & -31 & -11 & 51 & 47.1 & 0.37 \\
\hline$\beta$-OH-butyrate & 130 & 164 & 142 & 37.0 & 0.71 \\
\hline $\mathrm{NH}_{3}$ & -81 & -42 & 41 & 67.3 & 0.37 \\
\hline \multicolumn{6}{|l|}{ Splanchnic EE 2} \\
\hline PDV & 63 & 47 & 34 & 13.3 & 0.53 \\
\hline \multirow{2}{*}{$\begin{array}{l}\text { liver }^{1} \\
\text { splanchnic tissues }\end{array}$} & 65 & 48 & 42 & 5.6 & 0.12 \\
\hline & 130 & 91 & 87 & 16.6 & 0.23 \\
\hline
\end{tabular}

positive and negative values indicate net production and net uptake of the metabolite, respectively ${ }^{1}$ results shown as least squares means $(\mathrm{N}=2$ for $\mathrm{T} 0$, and 3 for each of $\mathrm{T} 30$ and $\mathrm{T} 60)$

2 based on $460 \mathrm{~kJ} / \mathrm{mol} \mathrm{O}_{2}$

a,b,c values in the same row with different superscripts are significantly different (Duncan's Multiple Range Test; $\mathrm{P}<0.01$ ) 
DE intake was similar across diets and averaged $477 \mathrm{~kJ} / \mathrm{kg}^{0.75} / \mathrm{d}$. Diet composition altered $\mathrm{PDV} \mathrm{NH}{ }_{4}^{+}$absorption (quadratic effect, $\mathrm{P}=0.04$ ), liver $\mathrm{NH}_{4}^{+}$ removal (quadratic effect, $\mathrm{P}=0.08$ ) and liver $\mathrm{B}-\mathrm{OH}$-butyrate production (quadratic effect, $\mathrm{P}=0.09$ ), but did not affect blood flow, net flux of glucose or lactate across the PDV, liver or the splanchnic tissues. The PDV and splanchnic net fluxes of $\beta$ $\mathrm{OH}$-butyrate were not affected by concentrate: forage ratio.

$\mathrm{O}_{2}$ consumption and EE by the PDV and splanchnic tissues were numerically lower in T30 and T60, but these changes did not reach statistical significance. A tendency $(\mathrm{P}=0.11)$ for a reduction in liver $\mathrm{O}_{2}$ consumption and $\mathrm{EE}$ (linear effect, $\mathrm{P}=0.06$ ) to 0.73 (T30) and 0.65 (T60) of that observed in forage fed animals was observed as the fraction of concentrate in the diet increased. This suggests that an extra 0.3-0.4 MJ/d (i.e. 0.04-0.05 of DE intake) might have been shifted from splanchnic to peripheral tissues with the diets containing concentrate. A similar energy sparing effect of concentrate rich diets was found by Reynolds et al. (1991) in heifers fed $75 \%$ concentrate or $75 \%$ pelleted lucerne diets at equal ME intake. However, this was associated with a significant reduction of $\mathrm{O}_{2}$ utilization by the PDV, with no significant change in that of the liver.

\section{CONCLUSIONS}

Increasing the concentrate: forage ratio at equal DE intake, reduced $\mathrm{PDV} \mathrm{NH}_{4}^{+}$ absorption as well as liver $\mathrm{NH}_{4}^{+}$removal and $\mathrm{B}-\mathrm{OH}$-butyrate production, but did not significantly change $\mathrm{O}_{2}$ consumption by the PDV or splanchnic tissues.

\section{REFERENCES}

Huntington G.B., 1989. Hepatic urea synthesis and site and rate of urea removal from blood of beef steers fed alfalfa hay or a high concentrate diet. Can. J. Anim. Sci. 69, 215-223

Milano G.D., Hotston Moore A., Lobley G.E., 2000. Influence of hepatic ammonia removal on ureagenesis, amino acid utilisation and energy metabolism in the liver. Brit. J. Nutr. 83, 307-315

Reynolds C.K., Tyrrell H.F., Reynolds P.J., 1991. Effect of diet forage-to-concentrate ratio and intake on energy metabolism in growing heifers: net nutrient metabolism by visceral tissues. J. Nutr. 121, 1004-1015 